\title{
Biocompatibility evaluation of bacterial cellulose as a scaffold material for tissue-engineered corneal stroma
}

\author{
Chen Zhang $\mathbb{D} \cdot$ Jingjie Cao $\cdot$ Shaozhen Zhao $\cdot$ Honglin Luo $\cdot$ Zhiwei Yang \\ Miguel Gama $\cdot$ Quanchao Zhang $\cdot$ Dan Su $\cdot$ Yizao Wan $(1)$
}

Received: 16 July 2019/Accepted: 2 January 2020 / Published online: 17 January 2020

(C) Springer Nature B.V. 2020

\begin{abstract}
In this work, biocompatibility of bacterial cellulose (BC) was assessed as the scaffold for corneal stroma replacement. Biocompatibility was evaluated by examining rabbit corneal epithelial and stromal cells cultured on the BC scaffold. The growth of primary cells was assessed by optical microscope, scanning electron microscope (SEM), and transmission electron microscope (TEM). Live/dead viability/cytotoxicity assay and CCK-8 assay were used to evaluate cell survival. BC was surgically implanted
\end{abstract}

C. Zhang $\cdot$ J. Cao $\cdot$ S. Zhao

Eye Institute and School of Optometry, Tianjin Medical University Eye Hospital, Tianjin 300384, People's

Republic of China

H. Luo $\cdot$ Z. Yang $\cdot$ Q. Zhang $\cdot$ Y. Wan

School of Materials Science and Engineering, East China Jiaotong University, Nanchang 330013, People's Republic of China

M. Gama

Centro de Engenharia Biológica, Universidade do Minho, Campus de Gualtar, 4715-057 Braga, Portugal

D. Su $(\square)$

College of Pharmacy, Jiangxi University of Traditional Chinese Medicine, Nanchang 330006, People's Republic of China

e-mail: sud94@aliyun.com

Y. Wan $(\bowtie)$

School of Materials Science and Engineering, Tianjin University, Tianjin 300072, People's Republic of China e-mail: yzwantju@126.com in vivo into a stromal pocket. During a 3-month follow-up, the biocompatibility of $\mathrm{BC}$ was assessed. We found that epithelial and stromal cells grew well on BC and showed a survival rate of nearly $100 \%$. The SEM examination for both kinds of cell showed abundant leafy protrusions, spherical projections, filopodia, cytoskeletons, and cellular interconnections. The stromal cells cultured on BC arranged regularly. TEM observation revealed normal cellular microstructure and a tight adhesion to the $\mathrm{BC}$ membrane. In vivo observation confirmed the optical transparency of $\mathrm{BC}$ during 3-month follow-up. The results demonstrated that $\mathrm{BC}$ had good biocompatibility for the tissue engineering of corneal stroma.

Keywords Bacterial cellulose - Corneal stroma . Tissue engineering $\cdot$ Biocompatibility
Abbreviations
BC Bacterial cellulose
SEM Scanning electron microscope
TEM Transmission electron microscope

\section{Introduction}

Cornea disease is the second leading cause of blindness, next only to cataract. Corneal transplant is the optimal treatment for patients with corneal blindness. 
Although corneal transplantation has achieved much clinical success (Ono et al. 2017), it has several limitations, such as the shortage of corneal tissue, graft failure, immune rejection, etc. To overcome the issue of tissue shortage, corneal tissue engineering has been developed and considerable advance has been made in the last 10 years. A suitable scaffold must be transparent, biocompatible, stable in vivo and able to integrate into the surround tissue. In previous studies, numerous scaffold materials have been investigated, including collagen (Xiao et al. 2014; Miyashita et al. 2006; Rafat et al. 2008), silk fibroin (Kim et al. 2018), and gelatin (Tonsomboon and Oyen 2013; Niu et al. 2014). However, these materials hardly meet the requirements for cornea regeneration, in particular concerning transparency, permeability to water and nutrients, mechanical robustness and stability (Niu et al. 2014). Therefore, seeking alternative scaffold materials is critical for the treatment of cornea disease.

In recent years, bacterial cellulose (BC), a natural polymer produced by bacteria, has attracted much attention for biomedical applications due to its high mechanical strength and elastic modulus, high water holding capacity and porosity, high crystallinity and polymerization, fine web-like network, and good biocompatibility (Pértile et al. 2012; Saska et al. 2012; Tazi et al. 2012; Picheth et al. 2017; Ullah et al. 2016). These characteristics make it very attractive in various biomedical applications, being currently used clinically as artificial skin (Jun et al. 2017; Keskin et al. 2017), wound dressing and replacement of the dura matter. Many other applications have been tested so far in pre-clinical trials: artificial blood vessels (Klemm et al. 2001), vascular grafts (Fink et al. 2011), and scaffolds for tissue engineering (Svensson et al. 2005; Wan et al. 2006; Liang et al. 2007; Dugan et al. 2013; Fang et al. 2009; Wan et al. 2007a, 2009). Importantly, BC possesses high light transmittance and favorable mechanical properties, being able to withstand surgical sutures and the intraocular pressure. BC is thus very promising as a potential scaffold for cornea (Picheth et al. 2017; Ullah et al. 2016). Previous studies have demonstrated the good potential of BC for cornea stromal cells growth (Picheth et al. 2017). However, no study so far has dealt with the behavior of epithelial cells on BC. Moreover, the sole in vivo study on the use of $\mathrm{BC}$ for cornea replacement, performed by Sepúlveda, demonstrated moderate inflammatory response (Sepúlveda et al. 2016), which contradicted with the in vitro studies. Therefore, there is an urgent need to verify the feasibility of BC as the cornea scaffold material.

In this study, the growth and proliferation of both rabbit corneal epithelial and stromal cells on the BC membrane were examined and the biocompatibility of $\mathrm{BC}$ membrane in vivo was investigated by implanting the $\mathrm{BC}$ membrane in corneal stromal pocket.

\section{Materials and methods}

Preparation of BC pellicles

As described previously (Wan et al. 2006, 2007b; Hong et al. 2006; Luo et al. 2016), the bacterial strain, Komagataeibacter xylinus X-2, provided by Tianjin University of Science and Technology, Tianjin, China, was grown in the culture medium containing $2.5 \%(\mathrm{w} /$ v) glucose, $0.75 \%(\mathrm{w} / \mathrm{v})$ yeast extract, $1 \%(\mathrm{w} / \mathrm{v})$ tryptone, and $1 \%(\mathrm{w} / \mathrm{v}) \mathrm{Na}_{2} \mathrm{HPO}_{4}$, which was sterilized at $121{ }^{\circ} \mathrm{C}$ for $30 \mathrm{~min}$, as described previously (Wan et al. 2006, 2007b, 2015; Xiong et al. 2015). The $\mathrm{pH}$ of the medium was adjusted to 4.5 with acetic acid and the culture time was $3 \mathrm{~h}$, yielding BC pellicles with a thickness of around $150 \mu \mathrm{m}$. The obtained BC pellicles were purified by soaking in deionized water at $80{ }^{\circ} \mathrm{C}$ for $3 \mathrm{~h}$ followed by boiling in $0.5 \mathrm{M} \mathrm{NaOH}$ solution for $2-3 \mathrm{~h}$. After rinsing with deionized water till neutral $\mathrm{pH}$, the $\mathrm{BC}$ pellicles were collected. Prior to cell culture, the $\mathrm{BC}$ pellicles $(35 \mathrm{~mm}$ in diameter and $150 \mu \mathrm{m}$ in thickness) were sterilized at $121^{\circ} \mathrm{C}$ for $50 \mathrm{~min}$. Then, the BC pellicles were washed 3 times with phosphate buffered saline (PBS). Finally, they were placed into F12 medium (Gibco, USA) containing $10 \%$ fetal bovine serum (FBS, Gibco, USA) for $48 \mathrm{~h}$ at $4{ }^{\circ} \mathrm{C}$.

Culture of rabbit primary corneal epithelial and stromal cells

Young adult New Zealand white rabbits of either gender, weighing 2-3 kg, were obtained from Tianjin Medical University, Tianjin, China. All animal experimental protocols were approved by the Ethics Committee of Tianjin Medical University Eye Hospital, Tianjin, China. After dissecting the corneas of the rabbits, the endothelial layers were surgically removed. Then using tunnel knife, the epithelial layer 
was separated from the stroma. We used tissue explant method for culturing epithelial and stromal cells. The cells were cultured in F12 medium and 10\% FBS at $37{ }^{\circ} \mathrm{C}$ under $5 \% \mathrm{CO}_{2}$ atmosphere. The cells reached confluence within 7 days and were detached enzymatically with $0.25 \%$ trypsin- $0.02 \%$ EDTA.

Morphology of corneal epithelial and stromal cells on $\mathrm{BC}$

The as-prepared $\mathrm{BC}$ pellicles were placed into a 6-well culture plate. The epithelial and stromal cells were seeded in the culture plate separately. Then, $500 \mu \mathrm{L}$ of cell suspension at a concentration of $2 \times 10^{4} / \mathrm{mL}$ was added into each well. The cells were cultured under the above conditions for another 5 days. The morphology of the cells was monitored with inverted phase contrast microscope.

\section{Cell viability assay}

The viability of the cells on BC was evaluated using a live/dead viability/cytotoxicity assay. After 5 days culture, the cells were washed with PBS 3 times. Then, the cells were incubated with $100 \mu \mathrm{L}$ of $4 \mu \mathrm{M}$ ethidium homodimer-1 $\mu \mathrm{M}$ calcein-AM (Molecular Probes, Eugene, OR) solution (Biovision, USA) for $20 \mathrm{~min}$ at room temperature and immediately observed with a fluorescence microscope $(485 \mathrm{~nm}$ as emission wavelength, $515 \mathrm{~nm}$ as excitation wavelength). The non-fluorescent calcein-AM is converted into green fluorescent polyanionic calcein by intracellular esterase, indicating viable cell metabolism. Ethidium homodimer is excluded by viable cells but permeates damaged cell membranes, binds to nucleic acids and results in red fluorescence. Green-stained (viable) and red-stained (non-viable) cells were counted in three wells (10 fields per well) at 400-fold magnification. The cells incubated on the culture plate without $\mathrm{BC}$ were stained as viable control, while the cells incubated with alcohol were used as non-viable control.

\section{Cell proliferation assay}

The proliferation of the cells on $\mathrm{BC}$ was evaluated using a Cell Counting Kit-8 (CCK-8, Solarbio, China). The suspension of epithelial and stromal cells at a concentration of $1 \times 10^{4} / \mathrm{mL}$ was added into 24 -well plates separately. The cells incubated on the culture plate without BC were used as control groups. The cells were cultured in F12 medium and 10\% FBS at $37{ }^{\circ} \mathrm{C}$ under $5 \% \mathrm{CO}_{2}$ atmosphere for 1,3 , and 5 days. $200 \mu \mathrm{L}$ of CCK-8/F12 medium was added to each well. Plates were incubated for $3 \mathrm{~h}$. The absorbance of the supernatant was measured at $450 \mathrm{~nm}$ using microplate reader (iMark, Bio Rad, USA).

\section{Scanning electron microscopy (SEM) observation}

Morphology of $\mathrm{BC}$ membrane (freeze-dried), cell morphology and its interaction with $\mathrm{BC}$ were studied using SEM. Corneal epithelial and stromal cells grown with $\mathrm{BC}$ were fixed with $2 \%$ glutaraldehyde in $0.1 \mathrm{M}$ PBS for $1 \mathrm{~h}$ at room temperature after 4-6 days culture on the scaffold. Samples were washed twice in PBS for 15 min and subsequently dehydrated through a graded series of ethanol aqueous solution (60\%, $70 \%, 80 \%, 90 \%$, and $99.9 \%, 30 \mathrm{~min}$ in each step). Subsequently, ethanol was replaced with tert-Butanol. Samples were stored at $4{ }^{\circ} \mathrm{C}$ until completely frozentransferred to $-80{ }^{\circ} \mathrm{C}$ for $24 \mathrm{~h}$, and then freeze-dried. The samples were sputter-coated with a thin layer of gold before SEM analysis.

Transmission electron microscopy (TEM) observation

Stromal cell organelle structure was observed with TEM. The samples were fixed with $2 \%$ glutaraldehyde in $0.1 \mathrm{M}$ PBS for $1 \mathrm{~h}$ at $37^{\circ} \mathrm{C}$ and rinsed in PBS 3 times. Stromal cells were further fixed in $1 \%$ osmium tetroxide with $0.1 \%$ potassium ferricyanide and subsequently dehydrated through a graded series of ethanol. After dehydration, the specimens were embedded in epoxy resin and ultrathin sections $(65 \mathrm{~nm})$ were sliced parallel and perpendicular to the alignment of the underlying fibrillar substrates. The sections were examined and photographed under a Hitchi-7650 transmission electron microscope (Japan).

\section{Surgery}

Under sterile conditions, 12 rabbits were anesthetized with intramuscular injection of ketamine hydrochloride and xylazine hydrochloride. A lamellar stromal pocket with a diameter of $5 \mathrm{~mm}$ was created with 
trephine and tunnel knife in the center cornea of the right eye. $\mathrm{BC}$ with a diameter of $3 \mathrm{~mm}$ and a thickness of $150 \mu \mathrm{m}$ was soaked in PBS for $30 \mathrm{~min}$ before the surgery and then inserted into the lamellar stromal pocket. Finally, the stromal pocket was sutured with 10-0 nylon. After surgery, levofloxacin eye drop was instilled three times daily for 3 days.

Pathology observation of $\mathrm{BC}$ in vivo

On day 1, 7, 30, and 90 post-surgery, rabbit corneas were examined with slit-lamp for smoothness, clarity, and vascularization. For pathology examination, the rabbits were sacrificed on day 7,30 , and 90 postsurgery. Their corneas were collected, fixed in paraformaldehyde, and embedded in paraffin for sectioning and hematoxylin and eosin (HE) staining.

\section{Results}

Morphology and transparency of BC membrane

The good transparency of BC membrane has been demonstrated by many previous studies including our groups (Wang et al. 2010; Gonçalves et al. 2015). The transparency of $\mathrm{BC}$ membrane prepared in this work is demonstrated in Fig. 1a. Figure 1b showed the nanofibrous structure of BC membrane, consistent with our previous work (Luo et al. 2018). Figure 1b also revealed that the $\mathrm{BC}$ membrane prepared in this work has a high transmittance of $92.7 \%$ at $700 \mathrm{~nm}$ wavelength.
Morphology of corneal epithelial and stromal cells on $\mathrm{BC}$

Inverted phase contrast microscope revealed cobblestone appearance of epithelial cells on BC (Fig. 2a) and spindle shape of stromal cells grown on $\mathrm{BC}$ (Fig. 2b).

\section{Live/dead viability/cytotoxicity assay}

The green live cells (Figs. 3a and 4a) and the red dead cells (Figs. 3 b and $4 b$ ) were shown as control groups. Note that the epithelial and stromal cells cultured on $\mathrm{BC}$ showed green fluorescence without red color. This suggests a nearly $100 \%$ survival rate (Figs. $3 \mathrm{c}$ and $4 \mathrm{c}$ ).

\section{CCK-8 assay}

CCK-8 assay results showed that the corneal epithelial cells on $\mathrm{BC}$ and tissue plates demonstrated almost identical proliferation on day $1(p=0.14, \mathrm{BC}$ vs. control) and day 3 ( $p=0.06$, BC vs. control), whereas on day 5 , cell growth on BC membrane was slightly slower when compared to control group ( $p<0.05$, BC vs. control). Although the stromal cells on $\mathrm{BC}$ grew more slowly than control group on day 1,3 , and 5 ( $p<0.05, \mathrm{BC}$ vs. control), the stromal cells on $\mathrm{BC}$ still exhibited robust proliferation, suggesting good biocompatibility of BC (Fig. 5).

\section{SEM and TEM observations}

The SEM observation showed that the epithelial cells grew well and were closely linked to BC. There were abundant leafy protrusions (Fig. 6a), microvilli and
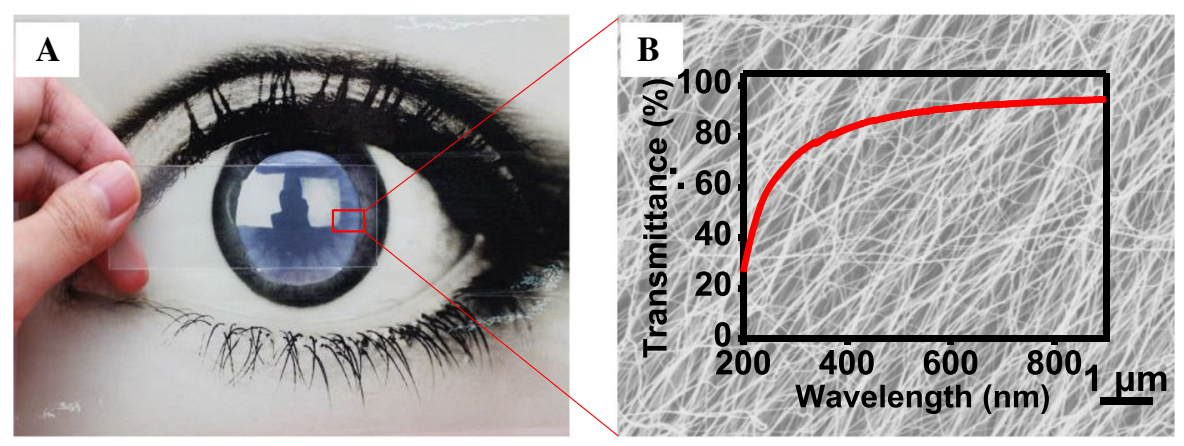

Fig. 1 a A photo of BC membrane showing its good transparency. b A SEM micrograph of BC membrane showing nanofibrous structure and high transmittance 

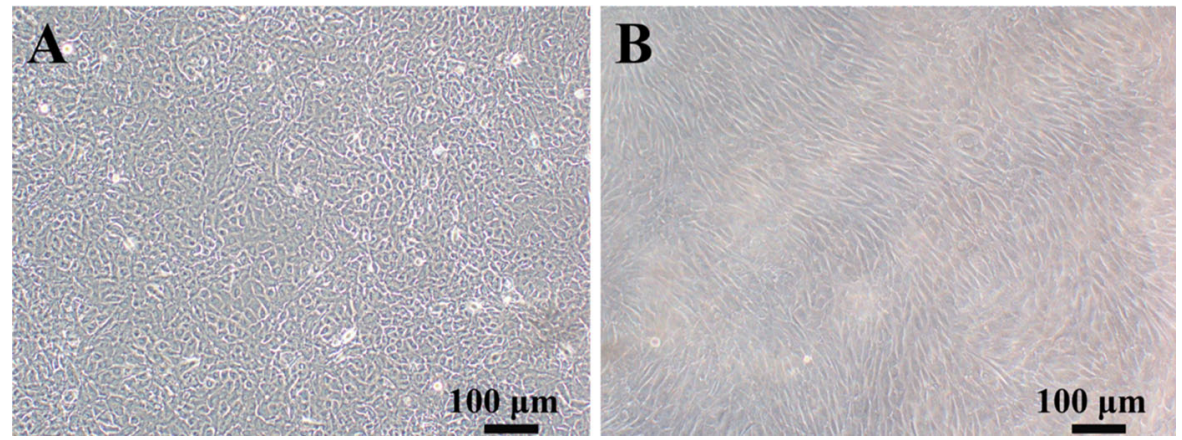

Fig. 2 a A photo of corneal epithelial cells on BC showing cobblestone appearance. b A photo of corneal stromal cells cultured on BC showing fibroblastic morphology
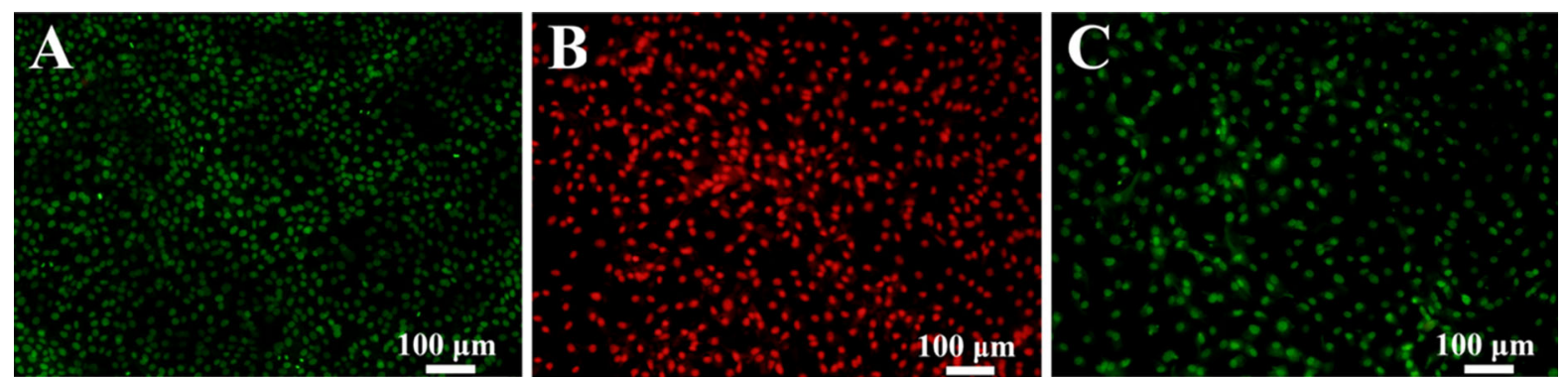

Fig. 3 Live/dead viability/cytotoxicity assay of the corneal epithelial cells. a The epithelial cells incubated on the culture plate without $\mathrm{BC}$ served as viable control and the viable epithelial cells showed green color; $\mathbf{b}$ The epithelial cells on the culture plate incubated with alcohol were used as non-viable control and the non-viable epithelial cells showed red color; c Epithelial cells cultured on BC showing only green fluorescence
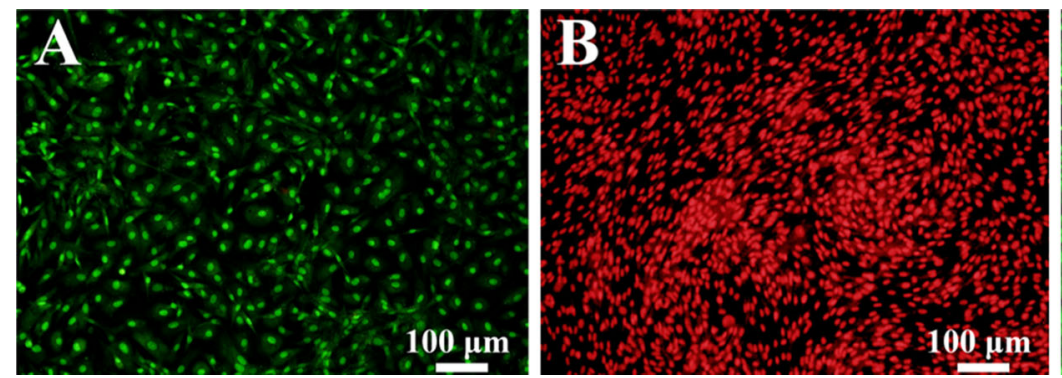

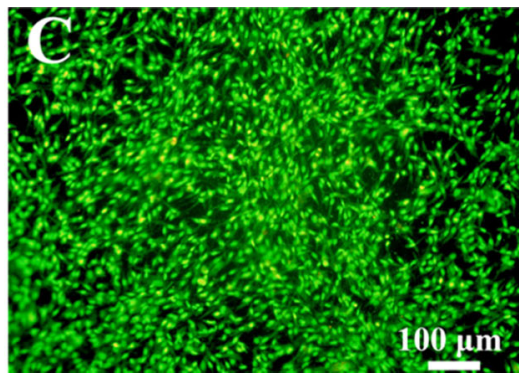

with alcohol were used as non-viable control and the non-viable stromal cells showed red color; c Stromal cells cultured on BC showing only green fluorescence

and pseudopodium of cells were noted (Fig. 7f). All these results suggest that the stromal cells grew well on BC. Moreover, the stromal cells were in the active state and the filopodia of the stromal cell were closely linked to BC.

TEM result showed that the organelle structures of all stroma cells were in normal condition (Fig. 8a). The stroma cell membrane that was in contact with BC connections (Fig 7e). Furthermore, the microvillus 

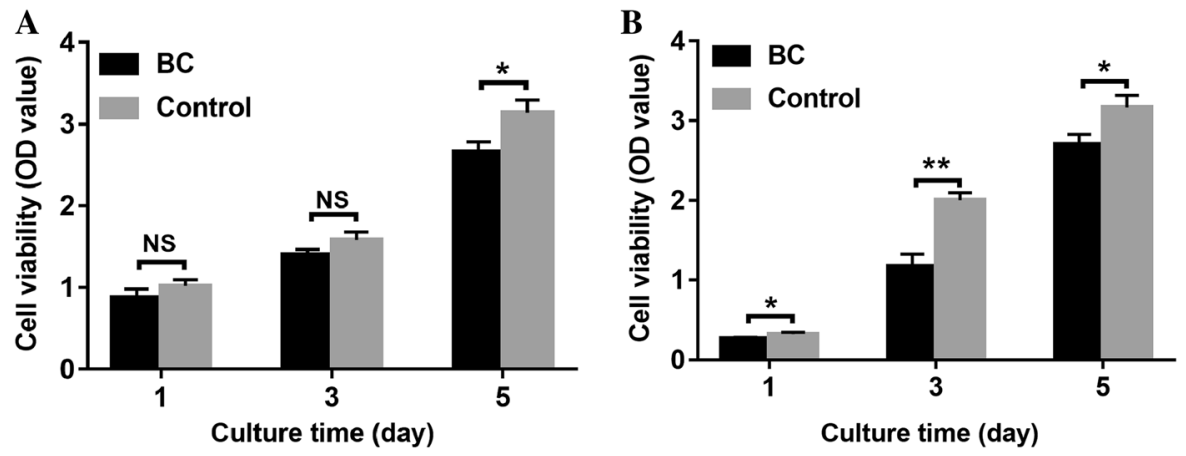

Fig. 5 The proliferation of corneal epithelial cells (a) and stromal cells (b) on BC detected using CCK-8 assay (n = 3/group). $T$ test was used to analyze the results. Data was presented as the mean \pm SD. $* p<0.05,{ }^{*} p<0.01$
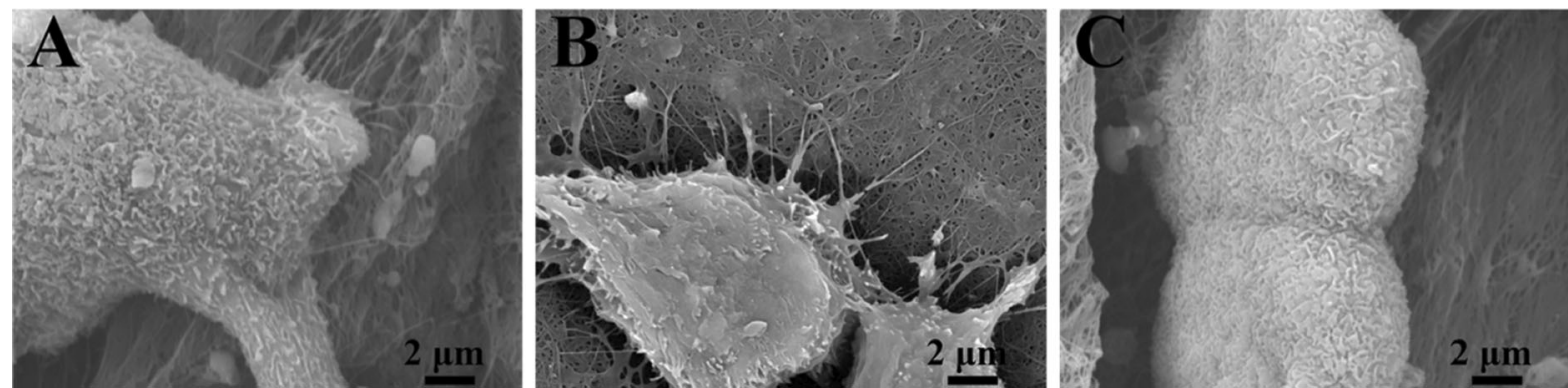

Fig. 6 SEM images of epithelial cells cultured on BC. a The leafy protrusions of the epithelial cells; b Microvilli and connections between cells; $\mathbf{c}$ The microvillus and pseudopodium of cells
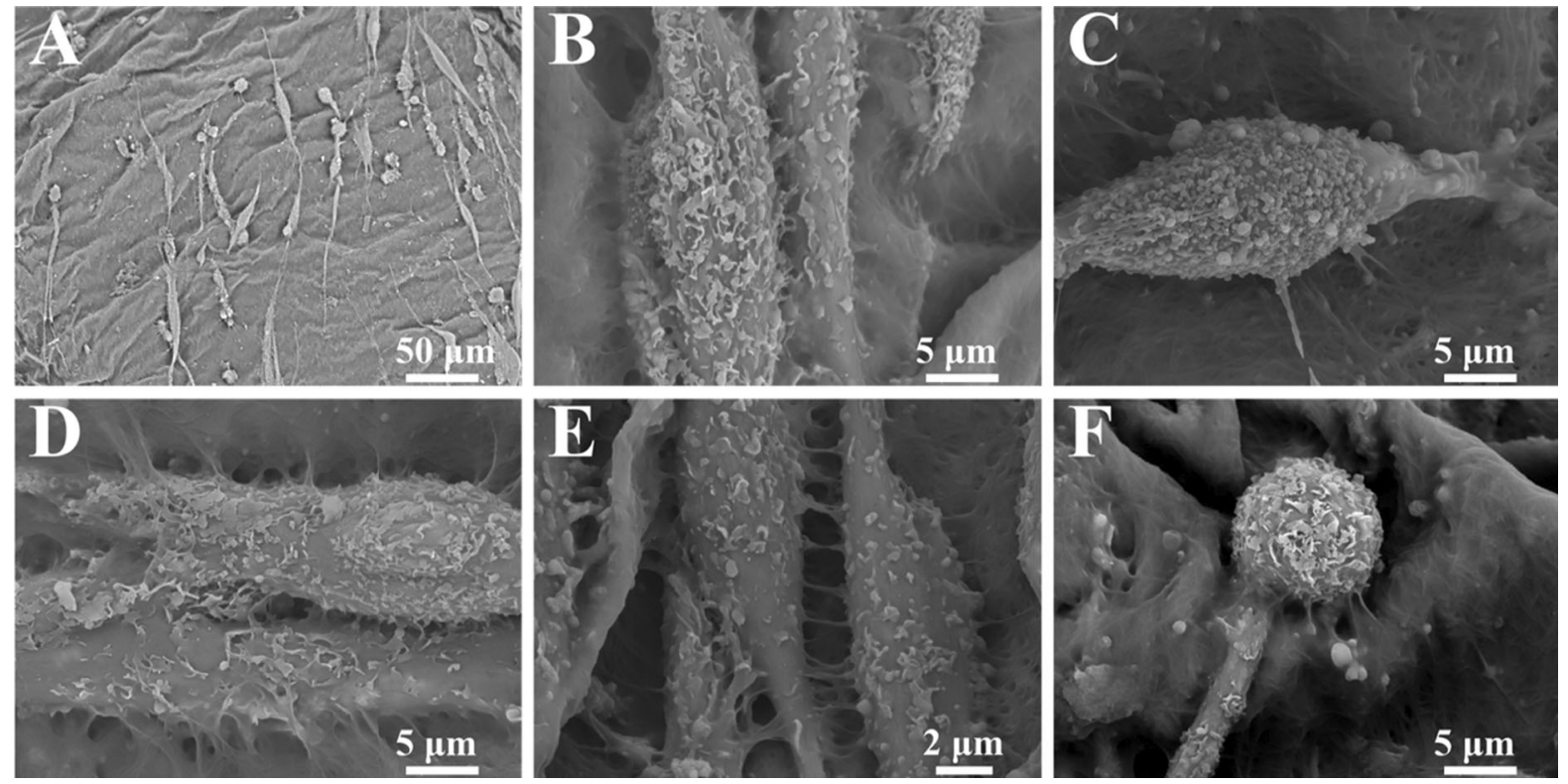

Fig. 7 SEM images of stromal cells cultured on BC. a Stromal cells grew regularly on the $\mathrm{BC}$ membrane; b The leafy protrusions of the stromal cells; $\mathbf{c}$ The spherical projections of the stromal cells; $\mathbf{d}$ The filopodia of the stromal cells; $\mathbf{e}$ The cell connections; $\mathbf{f}$ The microvillus and pseudopodium of cells 

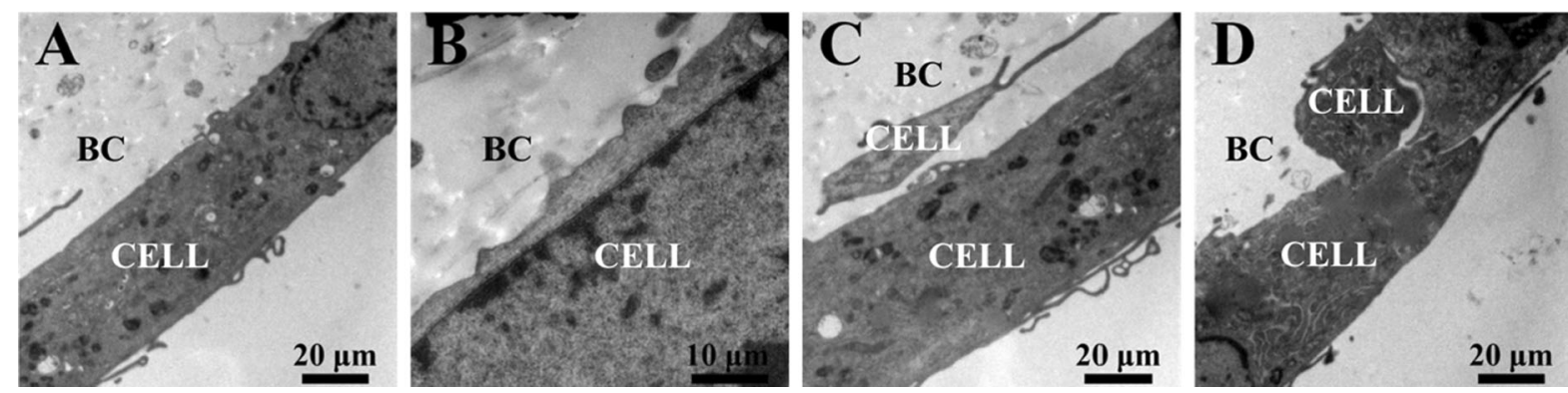

Fig. 8 TEM images of stromal cells cultured on BC. a The organelles of the stromal cells; $\mathbf{b}$ The cells in contact with BC; $\mathbf{c}$ The multiple layers of cell on BC; $\mathbf{d}$ The cell connections

had many protrusions (Fig. 8b). Figure 8c showed that there were multiple layers of cells on the surface of BC. Moreover, the connections between cells could be seen in Fig. 8d.

\section{Slit-lamp observation of BC in vivo}

$\mathrm{BC}$ was assessed according to the grading of clinical findings in corneal graft (Larkin et al. 1997). On the first day after surgery, the cornea of the rabbit demonstrated mild edema at the edge of the incision. The BC inserted was transparent and no infiltration in the cornea could be detected with a slit-lamp (Fig. 9a). By day 7 and 30 post-surgery, both the cornea and BC appeared transparent (Fig. 9b and c). The edge of BC could be detected with a slit-lamp. During the 90 days post-surgery period, the cornea and $\mathrm{BC}$ remained transparent (Fig. 9d). Figure 9 demonstrated that there was no new vascularization or infiltration detected in the cornea.

HE staining

The result of HE staining of corneal tissue section showed that the insertion of $\mathrm{BC}$ did not lead to inflammatory response on day 7 and the edge between
BC and stroma was not clear in cornea (Fig. 10a and b). By 30 days post-surgery, no obvious edema or inflammation around the $\mathrm{BC}$ was detected, and $\mathrm{BC}$ remained transparent (Fig. 10c and d). Moreover, the orderly array of layered structure of BC could be seen. Such condition remained stable up to 3 months postsurgery (Fig. 10e and f).

\section{Discussion}

The scaffold plays a crucial role in corneal tissue engineering because it provides the structure for cell growth (Liu et al. 2013). An ideal corneal stromal scaffold should be transparent with a fibrous structure similar to the biological corneal stroma. Furthermore, it must have good biocompatibility and no cell toxicity.

Many materials have been investigated for potential use in corneal tissue engineering. Previous studies showed the good biocompatibility of BC and its good interaction with corneal stromal cells. Nevertheless, no investigation on interaction with the corneal epithelial cells has been reported. Corneal epithelial cells constitute the outer protective layer of the tissue and preserve the integrity of the corneal stroma. In this
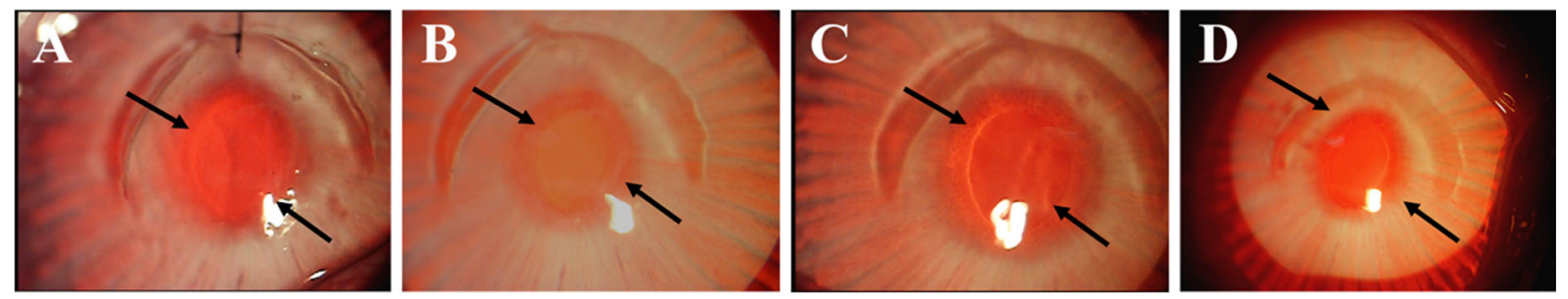

Fig. 9 Slit-lamp microscope photos of cornea. a 1 day after operation; b 7 days after operation; c 30 days after operation; d 90 days after operation. The arrows indicate $\mathrm{BC}$ in cornea 


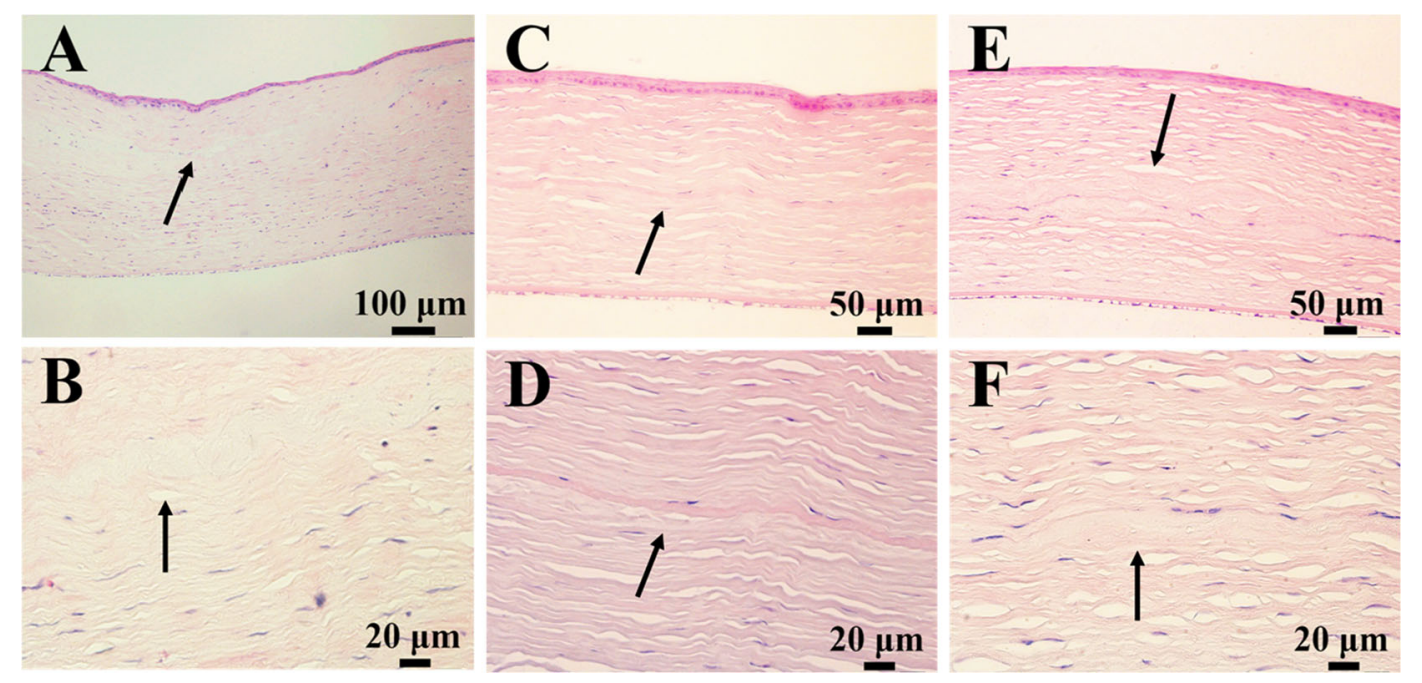

Fig. 10 HE staining of rabbit cornea. a, b 7 days after operation; c, $\mathbf{d} 30$ days after operation; e, $\mathbf{f} 90$ days after operation. The arrows point to $\mathrm{BC}$ in cornea

regard, corneal stromal and epithelial cells interaction with $\mathrm{BC}$ was assessed. We found that both kinds of cells grew well and attached efficiently to the BC. We also performed live/dead staining and CCK-8 assay for the viability of epithelia cells and stromal cells and confirmed the non-cytotoxicity of BC. SEM and TEM observations demonstrated that the epithelial and stromal cells were closely adhered to the BC and abundant microvilli and cell junctions were observed, which indicated healthy activity of cells on the BC. In addition, numerous filopodia and protrusions of cells membrane were connected to the fiber network of BC. Our results suggested that the BC scaffold could provide a favorable environment for the growth of both epithelial and stromal cells.

The light transmittance of normal cornea is $92 \%$ at $700 \mathrm{~nm}$ wavelength (Algvere et al. 1993). BC had a transmittance of $92.7 \%$, which was similar to that of human cornea in the range of visible light. Compared with other materials, $\mathrm{BC}$ had higher transmittance. For instance, the chondroitin sulfate had an average transmittance of $36.1 \%$ (Lai et al. 2012). The monolayer human amniotic membrane showed a transmittance of $86.5 \%$ and the 2-, 4-, and 6-layer amniotic membrane had a lower transmittance (Hariya et al. 2016). The average transmittance of the polymethylmethacrylate/cellulose nanocrystals composites was $60 \%$, which was much lower than BC (Liu et al. 2010). The maximum transmittance of the collagen- chondroitin sulfate membrane was more than $85 \%$ (Liu et al. 2016).

Unlike many previous works that conducted in vitro experiments, we conducted in vivo studies by adopting a protocol to further confirm the feasibility of BC as cornea scaffold material, which was different from that employed by Sepúlveda et al. who demonstrated moderate inflammatory process during the clinical observation after BC implantation (Sepúlveda et al. 2016). In Sepúlveda's work, a corneal ulcer was inflicted firstly, and an interlayer pocket from the base of the ulcer was made afterwards, for insertion and positioning of the membranes in the animals that received the membranes. Ulcer in cornea would cause obvious inflammation regardless of the presence of inserted BC. In other words, the inflammation may be caused by ulcer, rather than BC. In this work, we performed corneal stromal pocket and inserted BC into the pocket without corneal ulcer. Interestingly, we found that the inserted BC maintained its transparency without inflammation and neovascularization in HE staining and slit-lamp examination, which is an important feature for artificial cornea. Moreover, our in vivo experiment further revealed that the cornea remained transparent with no edema or inflammation during the 90 days post-operation. We believe that the discrepancy may be attributed to the different surgery procedures as compared to Sepúlveda et al. Overall, we found that $\mathrm{BC}$ membrane was stable, maintained its shape, and did not show obvious degradation. Our 
results strongly suggest that $\mathrm{BC}$ membrane has good biocompatibility and can be a promising tissue engineering scaffold material for corneal stroma, although further and more extensive evaluation of $\mathrm{BC}$ will be required.

\section{Conclusions}

In summary, in vitro cell culture experiment confirmed that BC supported cell adhesion, proliferation and differentiation, suggesting its excellent biocompatibility. The in vivo experiment further featured the good biocompatibility and stability of $\mathrm{BC}$ in rabbit cornea. These results indicate good potential for using $\mathrm{BC}$ as scaffold for artificial cornea. BC may be a fascinating option for tissue-engineered cornea stroma, but further and more extensive research is required to optimize its structure and function.

Acknowledgments This work is supported by the National Natural Science Foundation of China (Grant Nos. 81200663, 51572187, 51973058, and 31870963), Tianjin Clinical Key Discipline Project (Grant No. TJLCZDXKM014), and Key Research and Development Program of Jiangxi Province (No. 20192ACB80008, 20171BBG70112).

\section{Compliance with ethical standards}

Conflict of interest The authors declare that they have no conflict of interest.

\section{References}

Algvere PV, Torstensson P, Tengroth B (1993) Light transmittance of ocular media in living rabbit eyes. Invest Ophthalmol Vis Sci 34(2):349-354

Dugan JM, Gough JE, Eichhorn SJ (2013) Bacterial cellulose scaffolds and cellulose nanowhiskers for tissue engineering. Nanomedicine 8(2):287-298. https://doi.org/10.2217/ nnm.12.211

Fang B, Wan Y-Z, Tang T-T, Gao C, Dai K-R (2009) Proliferation and osteoblastic differentiation of human bone marrow stromal cells on hydroxyapatite/bacterial cellulose nanocomposite scaffolds. Tissue Eng A 15(5):1091-1098. https://doi.org/10.1089/ten.tea.2008.0110

Fink H, Hong J, Drotz K, Risberg B, Sanchez J, Sellborn A (2011) An in vitro study of blood compatibility of vascular grafts made of bacterial cellulose in comparison with conventionally-used graft materials. J Biomed Mater Res A 97A(1):52-58. https://doi.org/10.1002/jbm.a.33031

Gonçalves S, Padrão J, Rodrigues IP, Silva JP, Sencadas V, Lanceros-Mendez S, Girão H, Dourado F, Rodrigues LR (2015) Bacterial cellulose as a support for the growth of retinal pigment epithelium. Biomacromol 16(4):1341-1351. https://doi.org/10.1021/acs.biomac. $5 \mathrm{~b} 00129$

Hariya T, Tanaka Y, Yokokura S, Nakazawa T (2016) Transparent, resilient human amniotic membrane laminates for corneal transplantation. Biomaterials 101:76-85

Hong L, Wang YL, Jia SR, Huang Y, Gao C, Wan YZ (2006) Hydroxyapatite/bacterial cellulose composites synthesized via a biomimetic route. Mater Lett 60(13-14):1710-1713

Jun S-H, Lee S-H, Kim S, Park S-G, Lee C-K, Kang N-K (2017) Physical properties of TEMPO-oxidized bacterial cellulose nanofibers on the skin surface. Cellulose 24(12):5267-5274. https://doi.org/10.1007/s10570-0171508-2

Keskin Z, Sendemir Urkmez A, Hames EE (2017) Novel keratin modified bacterial cellulose nanocomposite production and characterization for skin tissue engineering. Mater Sci Eng C 75:1144-1153. https://doi.org/10.1016/j.msec.2017.03. 035

Kim DK, Sim BR, Kim JI, Khang G (2018) Functionalized silk fibroin film scaffold using $\beta$-Carotene for cornea endothelial cell regeneration. Colloid Surf B 164:340-346. https://doi.org/10.1016/j.colsurfb.2017.11.052

Klemm D, Schumann D, Udhardt U, Marsch S (2001) Bacterial synthesized cellulose-artificial blood vessels for microsurgery. Prog Polym Sci 26(9):1561-1603. https://doi.org/ 10.1016/S0079-6700(01)00021-1

Lai J-Y, Li Y-T, Cho C-H, Yu T-C (2012) Nanoscale modification of porous gelatin scaffolds with chondroitin sulfate for corneal stromal tissue engineering. Int $\mathbf{J}$ Nanomed 7:1101

Larkin D, Calder V, Lightman S (1997) Identification and characterization of cells infiltrating the graft and aqueous humour in rat corneal allograft rejection. Clin Exp Immunol 107(2):381-391

Liang H, Huang Y, He F, Ding HF, Wan YZ (2007) Enhanced calcium phosphate precipitation on the surface of mg-ionimplanted $\mathrm{ZrO}_{2}$ bioceramic. Surf Rev Lett 14(01):71-77. https://doi.org/10.1142/s0218625x07009086

Liu H, Liu D, Yao F, Wu Q (2010) Fabrication and properties of transparent polymethylmethacrylate/cellulose nanocrystals composites. Bioresour Technol 101(14):5685-5692

Liu X-Y, Chen J, Zhou Q, Wu J, Zhang X-L, Wang L, Qin X-Y (2013) In vitro tissue engineering of lamellar cornea using human amniotic epithelial cells and rabbit cornea stroma. Int J Ophthalmol 6(4):425-429. https://doi.org/10.3980/j. issn.2222-3959.2013.04.03

Liu Y, Lv H, Ren L, Xue G, Wang Y (2016) Improving the moisturizing properties of collagen film by surface grafting of chondroitin sulfate for corneal tissue engineering. J Biomater Sci Polym Ed 27(8):758-772

Luo H, Gu F, Xiong G, Hu D, Zhu Y, Wan Y (2016) A multichanneled bacterial cellulose scaffold for $3 \mathrm{D}$ in vitro cancer culture. Cell Chem Technol 50:49-56

Luo H, Dong J, Yao F, Yang Z, Li W, Wang J, Xu X, Hu J, Wan Y (2018) Layer-by-layer assembled bacterial cellulose/graphene oxide hydrogels with extremely enhanced mechanical properties. Nano Micro Lett 10(3):42. https:// doi.org/10.1007/s40820-018-0195-3

Miyashita H, Shimmura S, Kobayashi H, Taguchi T, AsanoKato N, Uchino Y, Kato M, Shimazaki J, Tanaka J, Tsubota 
K (2006) Collagen-immobilized poly (vinyl alcohol) as an artificial cornea scaffold that supports a stratified corneal epithelium. J Biomed Mater Res B 76B(1):56-63. https:// doi.org/10.1002/jbm.b.30332

Niu G, Choi J-S, Wang Z, Skardal A, Giegengack M, Soker S (2014) Heparin-modified gelatin scaffolds for human corneal endothelial cell transplantation. Biomaterials 35(13):4005-4014. https://doi.org/10.1016/j.biomaterials. 2014.01.033

Ono T, Ishiyama S, Hayashidera T, Mori Y, Nejima R, Miyata K, Amano S (2017) Twelve-year follow-up of penetrating keratoplasty. Jpn J Ophthalmol 61(2):131-136. https://doi. org/10.1007/s10384-016-0489-2

Pértile RAN, Moreira S, Gil da Costa RM, Correia A, Guãrdao L, Gartner F, Vilanova M, Gama M (2012) Bacterial cellulose: long-term biocompatibility studies. J Biomater Sci Polym Ed 23(10):1339-1354. https://doi.org/10.1163/ 092050611 X581516

Picheth GF, Pirich CL, Sierakowski MR, Woehl MA, Sakakibara CN, de Souza CF, Martin AA, da Silva R, de Freitas RA (2017) Bacterial cellulose in biomedical applications: a review. Int J Biol Macromol 104:97-106. https://doi.org/ 10.1016/j.ijbiomac.2017.05.171

Rafat M, Li F, Fagerholm P, Lagali NS, Watsky MA, Munger R, Matsuura T, Griffith M (2008) PEG-stabilized carbodiimide crosslinked collagen-chitosan hydrogels for corneal tissue engineering. Biomaterials 29(29):3960-3972. https://doi.org/10.1016/j.biomaterials.2008.06.017

Saska S, Scarel-Caminaga RM, Teixeira LN, Franchi LP, dos Santos RA, Gaspar AMM, de Oliveira PT, Rosa AL, Takahashi CS, Messaddeq Y, Ribeiro SJL, Marchetto R (2012) Characterization and in vitro evaluation of bacterial cellulose membranes functionalized with osteogenic growth peptide for bone tissue engineering. J Mater Sci Mater M 23(9):2253-2266. https://doi.org/10.1007/ s10856-012-4676-5

Sepúlveda RV, Valente FL, Reis ECC, Araújo FR, Eleotério RB, Queiroz PVS, Borges APB (2016) Bacterial cellulose and bacterial cellulose/polycaprolactone composite as tissue substitutes in rabbits' cornea. Pesquisa Veterinária Brasileira 36:986-992

Svensson A, Nicklasson E, Harrah T, Panilaitis B, Kaplan DL, Brittberg M, Gatenholm P (2005) Bacterial cellulose as a potential scaffold for tissue engineering of cartilage. Biomaterials 26(4):419-431. https://doi.org/10.1016/j. biomaterials.2004.02.049

Tazi N, Zhang Z, Messaddeq Y, Almeida-Lopes L, Zanardi LM, Levinson D, Rouabhia M (2012) Hydroxyapatite bioactivated bacterial cellulose promotes osteoblast growth and the formation of bone nodules. AMB Express 2(1):61. https://doi.org/10.1186/2191-0855-2-61
Tonsomboon K, Oyen ML (2013) Composite electrospun gelatin fiber-alginate gel scaffolds for mechanically robust tissue engineered cornea. J Mech Behav Biomed Mater 21:185-194. https://doi.org/10.1016/j.jmbbm.2013.03.001

Ullah H, Wahid F, Santos HA, Khan T (2016) Advances in biomedical and pharmaceutical applications of functional bacterial cellulose-based nanocomposites. Carbohyd Polym 150:330-352. https://doi.org/10.1016/j.carbpol. 2016.05.029

Wan YZ, Huang Y, He F, Wang YL, Zhao ZG, Ding HF (2006) Effect of Mg ion implantation on calcium phosphate formation on titanium. Surf Coat Technol 201(6):2904-2909

Wan YZ, Huang Y, He F, Li QY, Lian JJ (2007a) Tribological properties of three-dimensional braided carbon/Kevlar/ epoxy hybrid composites under dry and lubricated conditions. Mater Sci Eng A 452:202-209

Wan YZ, Huang Y, Yuan CD, Raman S, Zhu Y, Jiang HJ, He F, Gao C (2007b) Biomimetic synthesis of hydroxyapatite/ bacterial cellulose nanocomposites for biomedical applications. Mater Sci Eng C 27(4):855-864. https://doi.org/ 10.1016/j.msec.2006.10.002

Wan YZ, Gao C, Luo HL, He F, Liang H, Li XL, Wang YL (2009) Early growth of nano-sized calcium phosphate on phosphorylated bacterial cellulose nanofibers. J Nanosci Nanotechnol 9(11):6494-6500. https://doi.org/10.1166/ jnn.2009.1311

Wan Y, Yang Z, Xiong G, Guo R, Liu Z, Luo H (2015) Anchoring $\mathrm{Fe}_{3} \mathrm{O}_{4}$ nanoparticles on three-dimensional carbon nanofibers toward flexible high-performance anodes for lithium-ion batteries. J Power Sources 294:414-419

Wang J, Gao C, Zhang Y, Wan Y (2010) Preparation and in vitro characterization of BC/PVA hydrogel composite for its potential use as artificial cornea biomaterial. Mater Sci Eng C 30(1):214-218. https://doi.org/10.1016/j.msec.2009.10. 006

Xiao X, Pan S, Liu X, Zhu X, Connon CJ, Wu J, Mi S (2014) In vivo study of the biocompatibility of a novel compressed collagen hydrogel scaffold for artificial corneas. J Biomed Mater Res A 102(6):1782-1787. https://doi.org/10.1002/ jbm.a.34848

Xiong G, Luo H, Zhang C, Zhu Y, Wan Y (2015) Enhanced biological behavior of bacterial cellulose scaffold by creation of macropores and surface immobilization of collagen. Macromol Res 23(8):734-740

Publisher's Note Springer Nature remains neutral with regard to jurisdictional claims in published maps and institutional affiliations. 